\title{
Query
}

Q1. Please confirm if the forename and surname of all the authors are presented appropriately in the author byline here.

Q2. Please check if the edits made in the affiliation are correct.

Q3. Please provide keywords for this article as per journal style.

Q4. Please check if the inserted page number for Ref. [7] is correct or amend if necessary.

Q5. Please provide page range for Ref. [10].

Q6. Please provide English-translated reference details for Refs. [11]-[14]. 


\section{EPIDEMIOLOGICAL SITUATION OF MEASLES IN ROMANIA, ITALY, AND HUNGARY: ON WHAT THREATS SHOULD WE FOCUS NOWADAYS?}

26 contracted the infection before 10 years of age. In unvaccinated populations, $\mathrm{MeV}$

27 still causes periodic epidemics, with interepidemic period of $2-5$ years [1]. The

28 basic reproduction number $\left(R_{0}-\right.$ defined as the average number of secondary cases 29 of an infectious disease arising from a typical case in a totally susceptible

\footnotetext{
*Corresponding author; E-mail: orosz.laszlo@csongrad.gov.hu
}

\section{Introduction}

Measles virus (MeV) is the only member of the genus Morbillivirus that causes human disease [1]. Measles is highly contagious, susceptible individuals 4 have a $99 \%$ probability of acquiring the virus, if they come in close contact with 
population) for $\mathrm{MeV}$ is $12-18$, which is one of the highest known values [2]. $R_{0}$ also determines the herd immunity threshold and therefore the vaccination coverage required to achieve elimination. As $R_{0}$ increases, higher immunization level is required in the population (Figure 1) [2]. In the case of measles, the critical immunization threshold $\left(q_{\mathrm{c}}\right)$ is about $94 \%$ based on the following formula: $q_{\mathrm{c}}=1-1 / R_{0}$ (Figure 1) $[2,3]$.

In 2001, the World Health Organization (WHO) has launched a program to eliminate measles [3]. This is promising, because $\mathrm{MeV}$ is a human-specific virus, against which safe and potent vaccines are available [1]. Though the prevalence of wild-type $\mathrm{MeV}$ infection has decreased by $>90 \%$ in Europe, measles is still not eliminated and has even re-emerged with recurrent outbreaks in different countries, including Romania and Italy. Minor outbreaks of Romanian origin were reported from Hungary as well $[4,5]$. As EU citizens can travel freely in these countries, the chance of measles import into the neighboring areas increases. The aim of this work is to shed light on the current epidemiologic situation in these countries and on possible consequences for Hungary.

\section{Situation in Romania}

A measles outbreak in Romania has been ongoing since February 2016 [5]. As of October 2017, on the website of National Public Health Institute of Romania

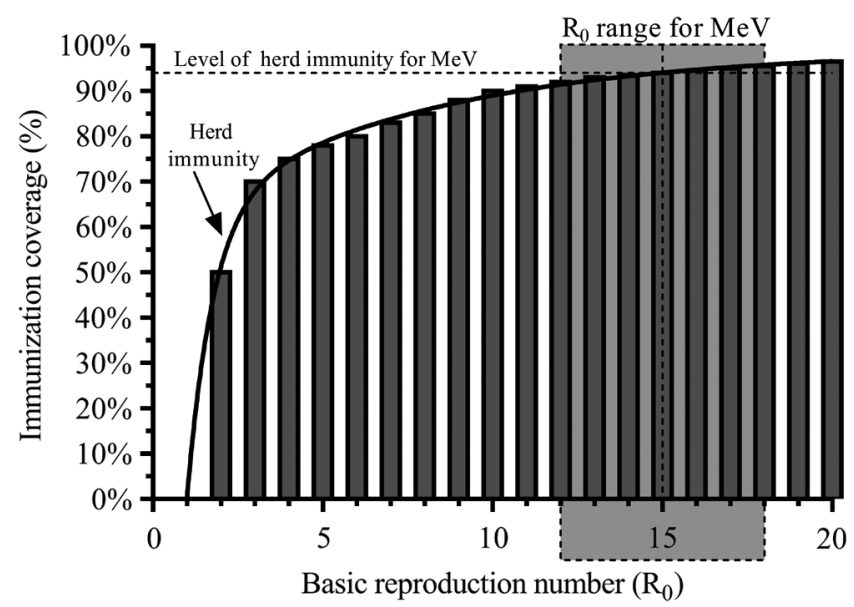

Figure 1. $\mathrm{MeV}$ basic reproduction number $\left(R_{0}\right)$, herd immunity, and immunization coverage. As $R_{0}$ the $R_{0}$ estimate of $12-18$, the characteristic value of measles [2] 
49 (INSP), 9,670 measles cases and 35 deaths were registered (http://cnscbt.ro/index. $50 \mathrm{php} /$ informari-saptamanale/rujeola-1). Based on the data of this website, the 51 prevalence of laboratory-confirmed cases, the incidence of new occurrences by 52 week, deaths, and mortality of the outbreak were calculated (Figure 2). The mean 53 mortality value is $0.44 \%$, which is higher than usual in the developed countries [6]. 54 Based on the data available on the website of INSP, $46 \%$ of deaths occurred 55 between 0 and 1 years of age, $40 \%$ between 1 and 10 years of age, and $14 \%$ of the 56 deceased were older than 10 years. In $60 \%$ of mortality, there were underlying 57 diseases detected. The cause of death was mostly pneumonia (91\%). None of the 58 deceased was vaccinated.

59 The continuous outbreak is driven presumably by poor surveillance quality 60 and suboptimal population immunity [4]. The vaccination coverage in Romania is 61 below 90\% [4].
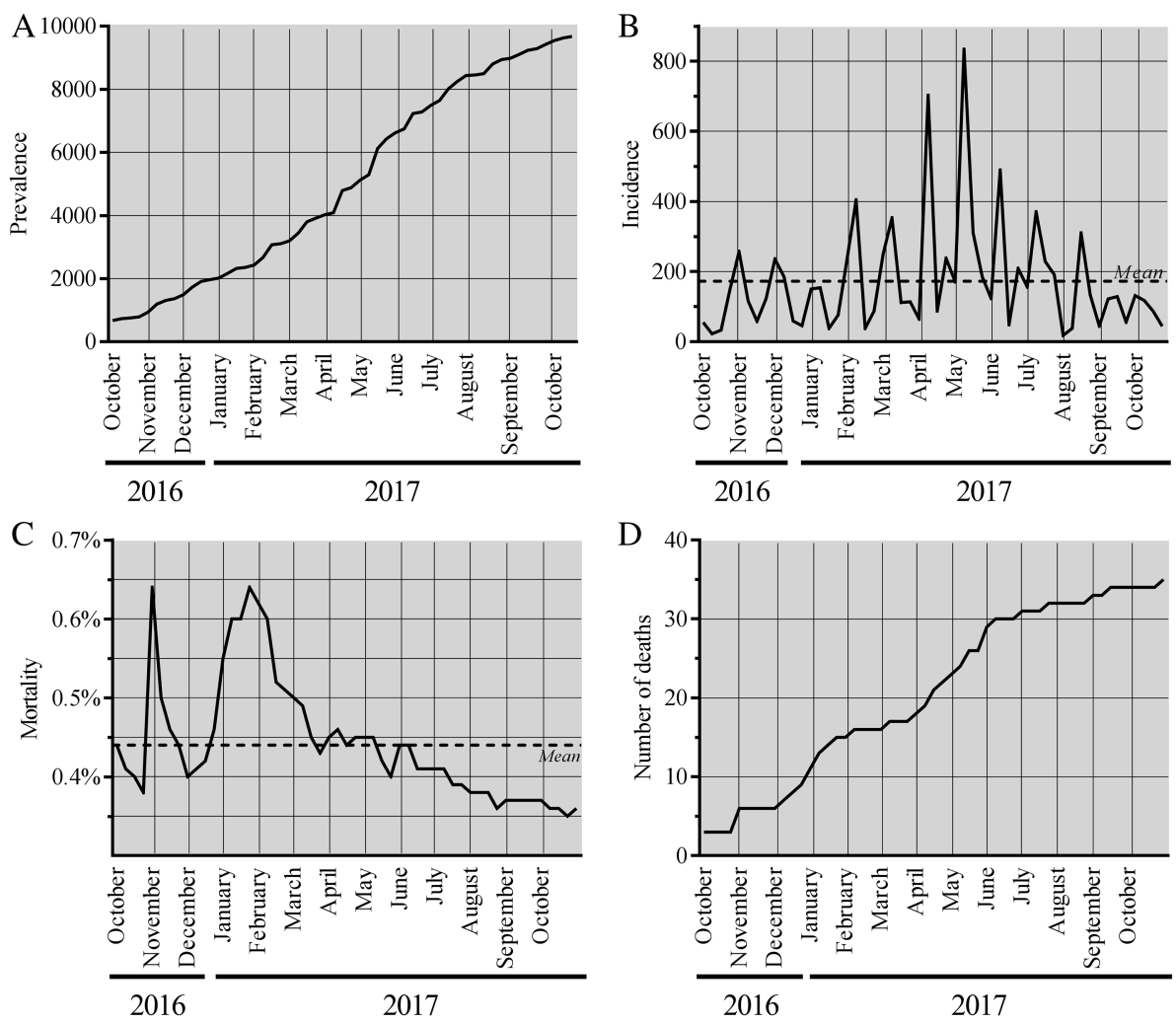

F2:1 Figure 2. (A) Prevalence, (B) incidence, (C) value of calculated mortality, and (D) number of death $\mathrm{F} 2: 2$ cases of the ongoing measles outbreak in Romania 
Thirty-eight out of the 41 Romanian counties are affected with the disease and in six of these, the morbidity rate per 100,000 people is higher than 99.01 (Figure 3). Among these six counties, three (Timiş, Arad, and Satu Mare) are located next to the Hungarian border (Figure 3).

\section{Situation in Italy}

In January 2017, the Italian National Health Institute (ISS) detected an increase in the number of measles cases. ISS immediately started to intensify surveillance and investigate the outbreak. Until the end of August 2017, 4,477 cases were reported to the surveillance system, of which $76.3 \%$ were laboratory-confirmed [7]. The current outbreak affected most of the Italian administrative regions (Figure 4) [7]. Based on the data of ISS, $88 \%$ of the cases were unvaccinated and $6.6 \%$ occurred among healthcare workers. Three deaths due to respiratory insufficiency were detected among children aged 16 months, 6 years, and 9 years, respectively. All of them were unvaccinated. Measles was laboratory-confirmed in all of the deceased children [7]. Based on the data of the WHO Measles Nucleotide Surveillance Database (MeaNS; www.who-measles.org), the strains turned from D8 to B3 genotype at the beginning of 2017. Vaccination coverage

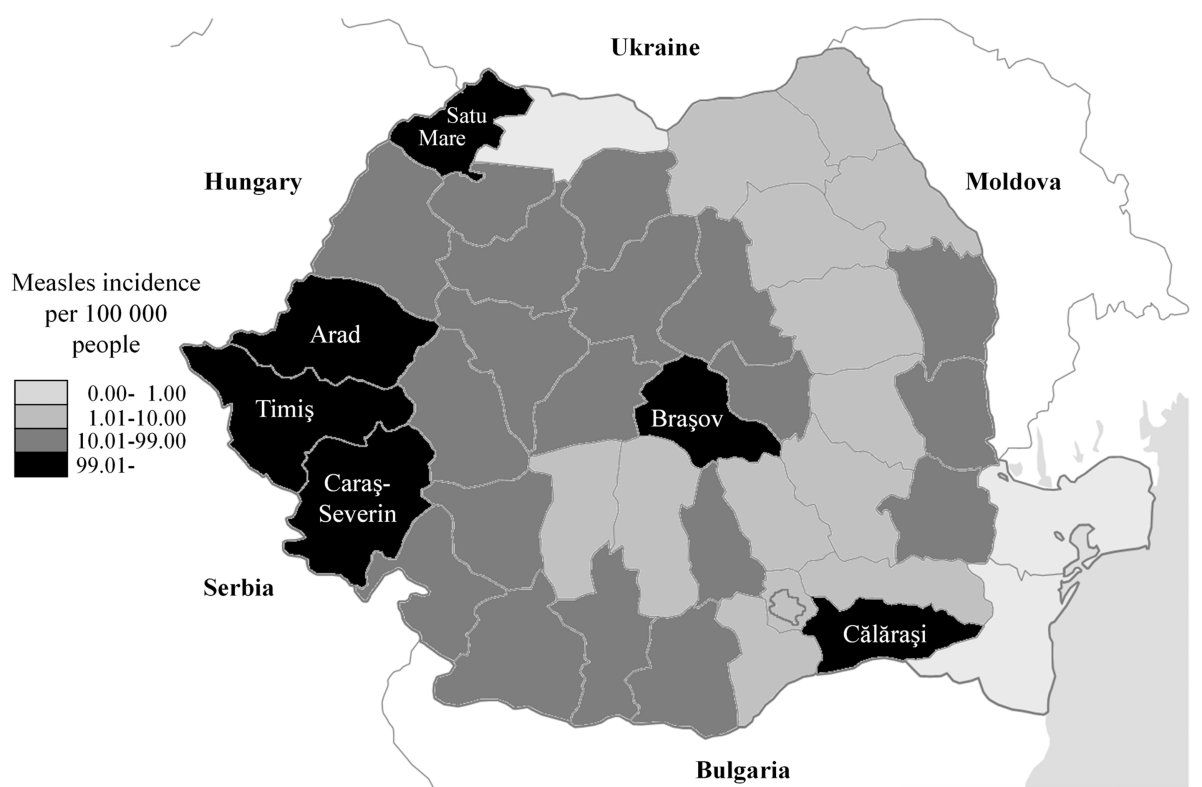




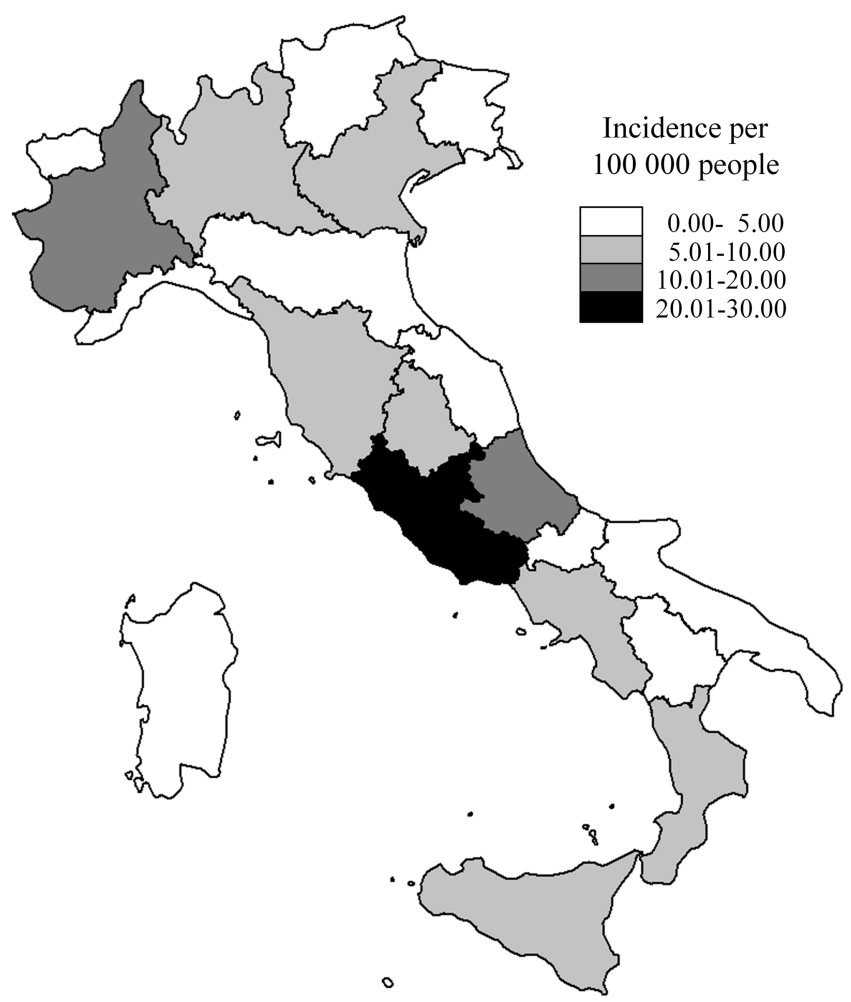

F $4: 1$

Figure 4. Measles incidence per 100,000 people in Italian provinces in 2017

79 is below $90 \%$ in Italy nowadays [7]. Decreased uptake of measles vaccine in the 80 country in recent years is the result of vaccine hesitancy.

81 The size of the described outbreak highlights that there are wide measles 82 immunity gaps in the Italian population, which is challenging to elimination [7]. 83 The connection between the Romanian and Italian epidemics cannot be ruled out, 84 since in the MeaNS database, the same genotype (B3) was registered during 2017.

86 The measles vaccination program is very effective in Hungary, since the 87 introduction of the mandatory vaccination in 1969 [8]. In 1984, the administration 88 of the vaccine was postponed from 12 to 15 months of age, to provide more 89 permanent immunity. To further strengthen the immunological reaction, revacci90 nation was also first organized in 1990 to decrease the number of persons without 
appropriate immune response $[8,9]$. As a result of the vaccination program, more than $99.5 \%$ of the population has been vaccinated, which eliminated the regular circulation of $\mathrm{MeV}$ in Hungary [8, 9]. However, lifelong immunity after active immunization is disputable due to primary or secondary vaccine failure $[3,10]$.

To support this, we examined the data about imported measles cases in the literature in 2017. To our knowledge, until October, three minor measles outbreaks were detected in the country. All of these outbreaks were derived from Romanian cases.

The first occurrences were detected from January 29, 2017 until March 10, 2017 in Makó and Szeged. During this period, 54 cases with measles-specific clinical symptoms were reported [5]. About 15 cases were confirmed and the remaining 39 could be excluded by laboratory methods. Based on sequencing of viral RNA genome, five cases revealed genotype B3 (data were kindly provided by Dr. Zita Rigó, National Reference Laboratory for Measles and Rubella, National Public Health Institute, Budapest, Hungary), which were identical with the Romanian and Italian genotypes based on the data of the MeaNS. Thus, the connection with the Romanian epidemic seems to be supported. In consequence of efforts and interventions, including active measles surveillance, quarantine, isolation, aspecific preventive measures (medical examination, education, and usage of protective equipment), observing in-patients, epidemiological monitoring of healthcare workers, immunological screening, and post-exposure vaccination, the public health office could successfully terminate the occurrence of further measles cases in Csongrád County. Of note, the high vaccination coverage (>99\%) of the Hungarian population also played an important role in this success [8]. However, the spread of the disease among vaccinated healthcare workers raises the possibility of secondary vaccine failure.

The second group of imported cases was detected at the end of July in Nyíregyháza, Szabolcs-Szatmár-Bereg County. Six unvaccinated Romanian children were admitted to hospital because of typical signs of measles. These cases were also confirmed by the National Reference Laboratory for Measles and Rubella [11]. The disease could spread among the Hungarian population, since the $\mathrm{MeV}$ infection of two healthcare workers (who were in close contact with the Romanian children) was also confirmed [11, 12].

The third group was consisted of four Romanian children, temporarily staying in Bács-Kiskun County. The patients were 9, 11, and 13 months and 2 years of age, none of them were vaccinated. These cases were also confirmed by the National Reference Laboratory for Measles and Rubella [13, 14]. There was no spreading detected among the Hungarian population [13, 14].

These data, in line with a recent study, raise the possibility of gaps in population-level immunity against measles in Hungary [15]. Several reports describe 
131 a significant proportion of secondary vaccine failure in populations with sustained 132 high vaccination coverage after long absence of $\mathrm{MeV}$ transmission with the resultant 133 lack of natural boosting, and waning of both the concentration as well as the avidity 134 of anti-measles IgG antibodies [10, 16-19]. Although avidity of antibodies may 135 slightly decrease with time, majority of the population with secondary vaccine 136 failure are characterized by antibodies of high-avidity index. Such outbreaks were 137 registered in Russia, Belarus, Germany, and Slovenia [10, 17, 18].

138 The finding that high proportions of secondary vaccine failure were detected 139 in countries with well working vaccination programs emphasizes the necessity of 140 studies assessing population immunity against MeV [10].

142 The authors would like to thank Dr. Zita Rigó (National Reference 143 Laboratory for Measles and Rubella, National Public Health Institute, Budapest, 144 Hungary) for presenting the genotype data of measles cases detected in Csongrád 145 County in 2017.

\section{Conflict of Interest}

The authors declare no conflict of interest.

\section{References}

1. Bellini, W. J., Icenogle, J. P.: Measles and rubella viruses. In Versalovic, J., Carroll, K. C., Funke, G., Jorgensen, J. H. (eds): Manual of Clinical Microbiology, $10^{\text {th }}$ Edition. ASM Press, Washington, 2011, pp. 1372-1387.

2. Guerra, F. M., Bolotin, S., Lim, G., Heffernan, J., Deeks, S. L., Li, Y., Crowcroft, N. S.: The basic reproduction number $\left(\mathrm{R}_{0}\right)$ of measles: A systematic review. Lancet Infect Dis 17, e420-e428 (2017).

3. Holzmann, H., Hengel, H., Tenbusch, M., Doerr, H. W.: Eradication of measles: Remaining challenges. Med Microbiol Immunol 205, 201-208 (2016).

4. Kriss, J. L., Stanescu, A., Pistol, A., Butu, C., Goodson, J. L.: The World Health Organization Measles Programmatic Risk Assessment Tool - Romania, 2015. Risk Anal 37, 1096-1107 (2017).

5. European Centre for Disease Prevention and Control: Epidemiological Update: Measles Monitoring European Outbreaks, 7 July 2017. ECDC, Solna, Sweden, 2017.

6. Rota, P. A., Moss, W. J., Takeda, M., de Swart, R. L., Thompson, K. M., Goodson, J. L.: Measles. Nat Rev Dis Primers 2, 16049 (2016). 
7. Filia, A., Bella, A., Del Manso, M., Baggieri, M., Magurano, F., Rota, M. C.: Ongoing outbreak with well over 4,000 measles cases in Italy from January to end August 2017 - What is making elimination so difficult? Euro Surveill 22, 30614 (2017).

8. Rigo, Z., Szomor, K. N., Nagy, O., Takacs, M.: Are we protected? Imported measles - On the way to eradication. Acta Microbiol Immunol Hung 59, 119-129 (2012).

9. Vegh, M., Hari-Kovacs, A., Roth, H. W., Facsko, A.: Ophthalmological symptoms of measles and their treatment. Orv Hetil 158, 1523-1527 (2017).

10. Santibanez, S., Prosenc, K., Lohr, D., Pfaff, G., Jordan Markocic, O., Mankertz, A.: Measles virus spread initiated at international mass gatherings in Europe, 2011. Euro Surveill 19 (2014).

11. Emberi Erőforrások Minisztériuma, O. T. F. F. H. Á., Kórházhigiénés és Járványügyi Felügyeleti Főosztály: Heti tájékoztató a hazai járványügyi helyzetről 2017. 31. hét. (2017).

12. Emberi Erőforrások Minisztériuma, O. T. F. F. H. Á., Kórházhigiénés és Járványügyi Felügyeleti Főosztály: Heti tájékoztató a hazai járványügyi helyzetről 2017. 33. hét. (2017).

13. Emberi Erőforrások Minisztériuma, O. T. F. F. H. Á., Kórházhigiénés és Járványügyi Felügyeleti Főosztály: Heti tájékoztató a hazai járványügyi helyzetről 2017. 35. hét. (2017).

14. Emberi Erőforrások Minisztériuma, O. T. F. F. H. Á., Kórházhigiénés és Járványügyi Felügyeleti Főosztály: Heti tájékoztató a hazai járványügyi helyzetről 2017. 34. hét. (2017).

15. Böröcz, K., Csizmadia, Z., Mészáros, V., Varga, V., Telek, V., Farkas, K., Balogh, P., Berki, T., Németh, P.: A measles vaccine efficacy study - Identifying potentially susceptible cohorts in Hungary. Immunol Q 9, 8-9 (2017).

16. Kontio, M., Jokinen, S., Paunio, M., Peltola, H., Davidkin, I.: Waning antibody levels and avidity: Implications for MMR vaccine-induced protection. J Infect Dis 206, 1542-1548 (2012).

17. Atrasheuskaya, A. V., Kulak, M. V., Neverov, A. A., Rubin, S., Ignatyev, G. M.: Measles cases in highly vaccinated population of Novosibirsk, Russia, 2000-2005. Vaccine 26, 2111-2118 (2008).

18. Atrasheuskaya, A. V., Blatun, E. M., Neverov, A. A., Kameneva, S. N., Maksimov, N. L., Karpov, I. A., Ignatyev, G. M.: Measles in Minsk, Belarus, 2001-2003: Clinical, virological and serological parameters. J Clin Virol 34, 179-185 (2005).

19. Pannuti, C. S., Morello, R. J., Moraes, J. C., Curti, S. P., Afonso, A. M., Camargo, M. C., Souza, V. A.: Identification of primary and secondary measles vaccine failures by measurement of immunoglobulin G avidity in measles cases during the 1997 Sao Paulo epidemic. Clin Diagn Lab Immunol 11, 119-122 (2004). 